\title{
Identification of Six Introns in a Partial Sequence of Echinococcus granulosus Paramyosin Gene
}

\author{
Echinococcus granulosus Paramiyozin Geninin Kısmi Dizilimindeki Altı İntronun \\ Tanımlanması
}

Majid Esmaelizad, Atefeh Ramezan, Nasser Razmaraii, Ali Mirjalili

Department of Biotechnology, Razi Vaccine and Serum Research Institute, Alborz, Karaj, Iran

\begin{abstract}
Objective: Paramyosin is a major protein produced by the metacestode cyst of Echinococcus granulosus, the causative agent of cystic hydatid disease. This protein has been shown to play an important role in modulating host immune responses. In this study, we attempted to characterize the noncoding sequence of the paramyosin gene.

Methods: Genomic DNA was isolated from G1 Iranian hydatid cysts. A DNA fragment of 3200 bp in length was amplified from the paramyosin gene. The polymerase chain reaction (PCR) product was cloned to the PTZ57T vector and sequenced by M13 primers and then compared with unique cDNA coding sequences of E. granulosus (Z21787) and Taenia solium (AY034087).

Results: Six introns I (107 bp), II (75 bp), III (47 bp), IV (921 bp), V (19 bp), and VI (456 bp) were identified in the partial sequence of the paramyosin gene. Some nucleotide changes were observed in three exons I, IV, and VI.

Conclusion: This data could help scientists in better understanding the possible alternative splicing and designing a real-time PCR technique for the evaluation of the transcription levels of paramyosin in the stages of the Echinococcus sp. life cycle. (Turkiye Parazitol Derg 2015; 39: 22-6)

Keywords: Echinococcus granulosus, paramyosin gene (Pmy), intron

Received: 25 Kasım $2013 \quad$ Accepted: 20 Kasım 2014

\section{ÖZET}

Amaç: Paramiyozin, kistik hidatik hastalığının etkeni olan E. granulosus'un metasestod kisti tarafından üretilen majör bir proteindir. Bu proteinin konakçının bağışıklık yanıtını modüle etmede önemli rol oynadığı gösterilmiştir. Bu çalışmada, paramiyozin geninin kodlama yapmayan dizisini karakterize etmeye çalıştık.

Yöntemler: Genomik DNA G1 İran hidatik kistinden izole edildi. Paramiyozin geninden 3200 baz çifti (bp) uzunluğunda bir DNA fragmanı amplifiye edildi. PCR ürünü pTZ57T vektörüne klonlandı ve M13 primerleri ile dizilendi ve sonra Echinococcus granulosus (Z21787) ve Taenia solium (AY034087) dizilerini kodlayan özgün cDNA ile karşılaştırıldı.

Bulgular: Paramiyozin geninin kısmi diziliminde, altı intron tanımlandı: I (107 bp), II (75 bp), III (47 bp), IV (921 bp), V (19 bp) ve intron VI (456 bp). Üç ekzonda (I, IV ve VI) bazı nükleotid değişiklikleri gözlendi.

Sonuç: Bu veriler Echinococcus sp. yaşam döngüsünün evrelerinde paramiyozinin transkripsiyon seviyelerinin değerlendirilmesinde gerçek zamanlı PCR tekniğinin olası alternatif zincirleme ve tasarımının daha iyi anlaşılması için bilim adamlarına yardımcı olabilir. (Turkiye Parazitol Derg 2015; 39: 22-6)
\end{abstract}

Anahtar Sözcükler: Echinococcus granulosus, paramiyozin geni (Pmy), intron

Geliş Tarihi: 25 Kasım 2013

Kabul Tarihi: 20 Kasım 2014

Address for Correspondence/ Yazışma Adresi: Dr. Majid Esmaelizad, Department of Biotechnology, Razi Vaccine and Serum Research Institute, Alborz, Karaj, Iran. Phone: 00982634570038 E-mail: m.esmaelizad@rvsri.ac.ir DOI: $10.5152 /$ tpd.2015.3452

CTelif hakkı 2015 Türkiye Parazitoloji Derneği - Makale metnine www.tparazitolderg.org web sayfasından ulaşılabilir. (C) Copyright 2015 Turkish Society for Parasitology - Available online at www.tparazitolderg.org 


\section{INTRODUCTION}

Paramyosin (Pmy) is the majority invertebrate filament protein (1). Pmy is an $\alpha$-helical protein that has been characterized as an integral muscle protein in invertebrates (2) such as Caenorhabditis elegans (3), Drosophila melanogaster (4), and a range of human parasites such as Schistosoma mansoni (5), Schistosoma japonicum (6), Onchocerca volvulus (7), Taenia solium (8), and Echinococcus granulosus (9). Pmy, which was previously named antigen $B(A g B)$, was used in some immunodiagnostic tests (10, 11). However, the genomic structure of this gene still remains unclear in some helminthes such as E. granulosus.

The Pmy protein was detected in the tegument of E. granulosus and $T$. solium. It is likely that the external and intra tegumental Pmy is produced by the subtegumental cells within cell bodies located under the outer muscle fibers (9).

On the other hand, Pmy may be formed within the muscle fibers. This protein is secreted into the tegument coating it and may pass to the external surface through it. An additional source for surface Pmy, at least in larvae, could be secretions of the post acetabular glands, as shown for S. japonicum cercariae (12). Pmy has revealed potential properties as a vaccine candidate against schistosomiasis and is a main serological immunodeterminant in immunized mice with non-living schistosomula $(13,14)$. In addition, vaccination of jirds with a Brugia malayi recombinant Pmy induces partial immunity to the Dirofilaria (15). Helminths Pmy have been planned as immunoregulatory molecules that modulate the immune system by repressing the classical pathway of the complement cascade via the inhibition of complement C1 function in the host (8). They are involved in the immunological protection mechanism of parasites by acting as Fc receptors and induce allergenic responses in humans. These results suggested that Pmy of helminths are multifunctional proteins. Pmy not only acts as an immunoregulatory molecule interacting with the host immune system but also acts as a structural protein in muscle layers to control their contraction physiologically (16). Taenia solium paramyosin (TPmy) is a prominent antigen in human cysticercosis that shows the ability to bind collagen (17). Immunization with syn VW2-1 (amino-terminal fragment of TPmy) reduced $43 \%-48 \%$ of the parasite load; these values were close to the $52 \%$ obtained with the recombinant product (18).

The evidence of producing isoforms because of alternative splicing for Pmy in Drosophila was observed in a study (19). The sequence of the exon for mPmy, which is located on the intron flanked by exons VII and VIII in the D. melanogaster gene, was not found on the homologous intron of the TPmy gene that is naked by exons 10 and 11; the intron size between these two exons is smaller (244 bp) than the size of exon mPmy (524 bp), thus leaving no room for the alternative splicing exon in T. solium (19). The structure of Pmy genes is only available for D. melanogaster (1) and C. elegans (3). The T. solium Pmy gene was 6,106 bp long from the start to the stop translation codons, containing $57.5 \%$ of intervening sequences in 13 introns, whereas the genes in D. melanogaster and C. elegans are 9,003 and 11,432 bp long, with a content of $76.9 \%$ and $70.5 \%$ intervening sequences in eight and 10 introns, respectively (19). The predicted amino acid sequence for $E$. granulosus larvae showed $71.4 \%$ identity to the
Schistosoma mansoni Pmy and a significant homology to a 17 amino-acid peptide sequence from antigen $B$ of $T$. solium. These data concluded that EG36 is the Pmy of E. granulosus. Immunoblot analysis revealed the expression of a 97-kDa protein in the E. coli clone and that of a protein with a similar molecular weight in protoscolices from E. granulosus and E. multilocularis as well as in E. granulosus cyst fluid (9).

Immunofluorescence studies showed that EG36 was localized throughout the tegument of E. granulosus and E. multilocularis larvae (9). The genomic structure of Pmy gene in E. granulosus was unclear. In this study, we attempted molecular analysis of $E$. granulosus Pmy gene at the DNA level.

\section{METHODS}

Hydatid cysts were collected from the infected tissues of sheep. The DNA was extracted from the germinal layer of cyst by the phenol-chloroform-isoamyl alcohol method, as described previously (20). Two primers were designed with the Oligo version 5.0 software (Wojciech Rychlik, National Biosciences, Inc, USA): forward 5'-CAT GGA TCC ATG TCT GAA TCA CAC GTC AAG-3' and reverse 5'-CCG CTC GAG CGC TCA TGT TCA GCA ATA TC-3'. Polymerase chain reaction (PCR) was performed in a $50 \mu \mathrm{L}$ reaction mixture containing $5 \mu \mathrm{L}$ of $10 \mathrm{x}$ reaction buffer, $1 \mu \mathrm{L}$ of mixed dNTPs (2.5 mM each), 1 unit Taq DNA polymerase enzyme (Roche Diagnostic, Germany), 10 pmol of each primer, $100 \mathrm{ng}$ of DNA template, $1.5 \mathrm{mM} \mathrm{MgCl}_{2}$, and deionized water up to $50 \mu \mathrm{L}$. The PCR program was conducted at $94^{\circ} \mathrm{C}$ for $3 \mathrm{~min}, 35$ cycles of $94^{\circ} \mathrm{C}$ for $30 \mathrm{~s}, 52^{\circ} \mathrm{C}$ for $30 \mathrm{~s}, 72^{\circ} \mathrm{C}$ for $3 \mathrm{~min}$, and $72^{\circ} \mathrm{C}$ for $5 \mathrm{~min}$.

Cloning of PCR product and DNA sequencing:

The PCR product was purified by the PCR product purification kit (Roche Diagnostic, Germany). The PCR product of the Pmy gene was electrophoresed to low melting point (LMP) agarose, and the distinct band was purified from the gel. The ligation reaction prepared with plasmid T-vector in $0.165 \mu \mathrm{g}, 0.18 \mathrm{pmol}$ ends and 0.54 pmol ends purified PCR fragment, 1x ligation buffer, $1 \mu \mathrm{L}$ PEG 4000 solution, 5 units of T4 DNA ligase, and deionized water up to $30 \mu \mathrm{L}$. The ligation mixture was incubated at $22^{\circ} \mathrm{C}$ for $16 \mathrm{~h}$. The ligation product was transformed to E. coli, strain Xl1blue, and the white colony was selected by the LcZ genetic marker and direct colony PCR (20). The positive plasmid was purified and sequenced by M13 primers (MWG Co., Germany). The sequences were analyzed using BLAST software (NCBI, USA).

\section{RESULTS}

A partial sequence of the EgPmy gene of $3200 \mathrm{bp}$ in length was sequenced by M13 primers and was compared to the unique coding sequence of E. granulosus (Z21787) and T. solium (AY034087) in GenBank (Figure 1). The results identified six introns and seven exons in the partial sequence of the Pmy gene of E. granulosus (Table 1). No homologous sequence was found in the nucleotide database of NCBI for identified introns. In this study, the size and position of six introns in the Pmy gene were identified (Figure. 1, 2a-c).

Six introns I (107 bp), II (75 bp), III (47 bp), IV (921 bp), V (19 bp), and $\mathrm{VI}(456 \mathrm{bp})$ were identified in the sequenced fragment. The 
position of different introns and exons were characterized (Figure 1, 2a-c). Different nucleotide changes were observed in exons I, IV, and VI of the Iranian G1 isolate (Figure 2a-c).

Bioinformatic tools (Blast software, NCBI) demonstrated seven high similar sequences in nucleotide positions (469-716), (198394), (2218-2305), and (3091-3162) with $100 \%$ similarity with nucleotide sequences (824-577), (1021-825), (332-245), (188-117) of unique E. granulosus Pmy mRNA (Z21787), respectively (Table 1). The other nucleotide position 2565-2635 showed 93\% identity with nucleotide sequences 252-183 of E. granulosus Pmy mRNA and sequences $37-94$ showed only $98 \%$ similarity to the nucleotide position 1076-1019 of E. granulosus mRNA. A lower similarity was found at positions 1184-1270 and 579-501 of Pmy mRNA with $84 \%$ similarity (Table 1). These seven similar sequences were

Table 1. Comparison of the levels of Echinococcus granulosus Pmy in cDNA (EgPmy cDNA) and DNA (EgPmy gene)

\begin{tabular}{|l|c|c|c|}
\hline EgPmy gene & EgPmy cDNA & Identity \% & Length bp \\
\hline $37-94$ & $1076-1019$ & 98 & 57 \\
\hline $198-394$ & $1021-825$ & 100 & 196 \\
\hline $469-716$ & $824-577$ & 100 & 247 \\
\hline $1184-1270$ & $579-501$ & 84 & 86 \\
\hline $2218-2305$ & $332-245$ & 100 & 87 \\
\hline $2565-2635$ & $252-183$ & 93 & 70 \\
\hline $3091-3162$ & $188-117$ & 100 & 71 \\
\hline \multicolumn{4}{|l|}{ EgPmy: echinococcus granulosus paramyosin gene } \\
\hline
\end{tabular}

Table 2. Comparison of the Echinococcus granulosus and Taenia solium Pmy sequence

\begin{tabular}{|l|c|c|c|c|}
\hline $\begin{array}{l}\text { EgPmy nucleotide } \\
\text { position }\end{array}$ & $\begin{array}{c}\text { TsPmy nucleotide } \\
\text { position }\end{array}$ & $\begin{array}{c}\text { Identity } \\
\%\end{array}$ & $\begin{array}{c}\text { Gaps } \\
\%\end{array}$ & Length \\
\hline $37-940$ & $4865-3982$ & 82 & 3 & 903 \\
\hline $2090-2103$ & $4900-4887$ & 100 & 0 & 13 \\
\hline $2114-2158$ & $2495-2451$ & 78 & 0 & 44 \\
\hline $2180-2867$ & $2406-1724$ & 69 & 7 & 687 \\
\hline $2953-3163$ & $1713-1506$ & 76 & 6 & 210 \\
\hline $\begin{array}{l}\text { EgPmy: echinococcus granulosus paramyosin gene; TsPmy: taenia solium } \\
\text { paramyosin gene }\end{array}$
\end{tabular}

exons in the coding region. Because our results showed that there are six introns between these coding sequences, the first intron was identified as a $107 \mathrm{bp}$ sequence, and the other introns with $75 \mathrm{bp}, 47 \mathrm{bp}, 921 \mathrm{bp}, 19 \mathrm{bp}$, and intron VI with $456 \mathrm{bp}$ were characterized.

When comparative analysis of the Pmy gene sequences of $E$. granulosus (EgPmy) with T. solium (TsPmy) (AY034087.1) was performed, the results showed an identity of $82 \%$ between nucleotide sequences 37-940 of E. granulosus Pmy and nucleotide sequences 4865-3982 of the TsPmy gene and included 3\% gaps. A lower percentage of identity can be found between nucleotide sequences 2180-2867 of EgPmy and nucleotide sequences 2406-1724 of TsPmy gene with 69\% identity and 7\% gaps. The third similar nucleotide sequences were found in sequences 2953-3163 of the EgPmy gene and nucleotide sequences 17131506 of the TsPmy gene with $76 \%$ identity and $6 \%$ gaps (Table 2).

\section{DISCUSSION}

Based on the known complete sequence of Drosophila Pmy in a previous study, some evidence of alternative splicing and isoform development of this protein was observed (19).

The sequence of the exon for $D$. melanogaster mPmy, located on the intron flanked by exons VII and VIII in the D. melanogaster gene, was not found on the homologous intron of the TPmy gene that is naked by exons 10 and 11; the intron size between these two exons is smaller (244 bp) than the size of exon mPmy (524 bp), leaving no room for the alternative splicing exon in $T$. solium (21). The structure of Pmy genes is well known for $D$. melanogaster (1) and C. elegans (3). The predicted amino acid sequence for $E$. granulosus larvae showed $71.4 \%$ identity to the Schistosoma mansoni Pmy and a significant homology to a 17 amino acid peptide sequence from antigen $B$ of $T$. solium.

Paramyosin is a muscle protein that probably plays a role in the survival of the larval stage of $T$. solium during its prolonged host-parasite relationship. T. solium Pmy contains 13 introns delimited by conventional eukaryotic splice signals. Comparison with the Pmy genes of D. melanogaster and C. elegans showed a lack of conservation of the exon/intron organization in contrast to other muscle genes.

The genomic structure of the Pmy gene in E. granulosus (EgPmy) was unclear. In this study, we attempted to identify the noncoding sequences of the EgPmy gene in the Iranian G1 isolate. For first time, six introns and seven exons in the partial sequence of

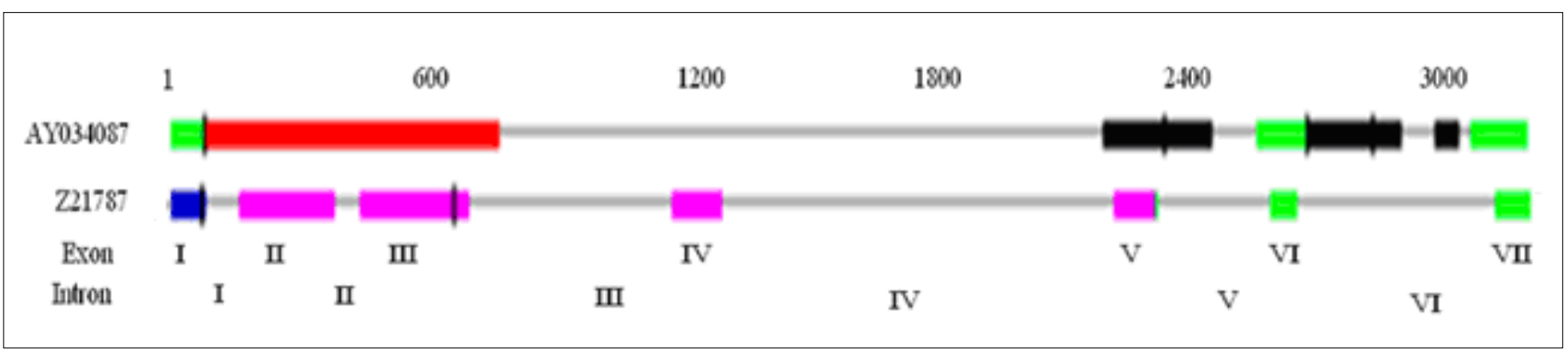

Figure 1. Comparative analysis of the $3200 \mathrm{bp}$ fragment of the Pmy gene with the cDNA coding sequence of Echinococcus granulosus (Z21787) and the sequence of Taenia solium (AY034087) using BLAST software 

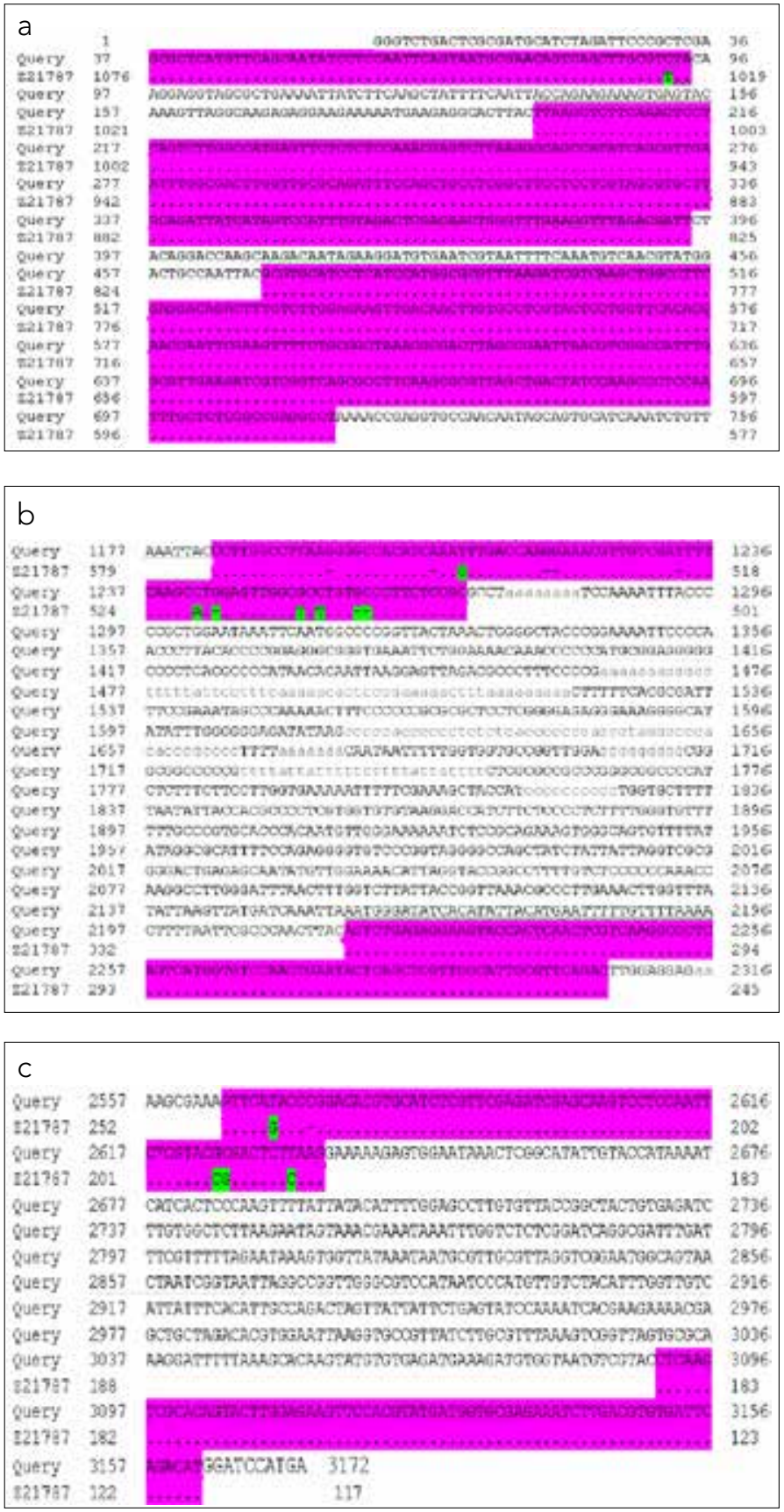

Figure 2. a-c. Identification of seven exons and six introns in the partial sequence of EgPmy genethe (a-c)

the Pmy gene of a G1 isolate of E. granulosus were identified. Comparison with T. solium Pmy sequence showed 69\%-82\% identity in five regions with EgPmy. Sequencing of the noncoding region could help scientists in better understanding the possible alternative splicing and other characteristics in the EgPmy gene.

Successful real-time PCR for the evaluation of the transcription level of specific mRNA depends on the ability to amplify a short specific product from mRNA. Classically, this means that primers should be on both sides of an intron (22). It is possible to amplify cDNA without any genomic DNA contamination. Effective design requires the sequence information on the genomic DNA of a gene (22).

\section{CONCLUSION}

Thus, this data could be used to design specific primers for the evaluation of gene expression levels of Pmy in different stages of the Echinococcus sp. life cycle using real-time PCR.

Ethics Committee Approval: Ethics Committee Approval was not received due to the retrospective nature of the study.

Informed Consent: Informed consent was not received due to the retrospective nature of the study.

Peer-review: Externally peer-reviewed.

Author Contributions: Consept - M.E.; Design - M.E.; Supervision - M.E.; Data Collection and/or Processing - A.R., N.R.; Analysis and/or Interpretation - M.E.; Literature Review - A. R.; Writer - M.E.; Critical Review - A.M.

Acknowledments: We would like to thanks our colleagues; Mrs. Hashemnejad and Mr. Hejazi for assistant in this research.

Conflict of Interest: No conflict of interest was declared by the authors.

Financial Disclosure: This work was supported by Razi Vaccine and Serum Research Institute.

Etik Komite Onayı: Çalışmamızın retrospektif tasarımından dolayı etik kurul onayı alınmamıştır.

Hasta onamı: Yazılı hasta onamı bu çalışmaya katılan hastalardan alınmıştır.

\section{Hakem Değerlendirmesi: Dış Bağımsız.}

Yazar Katkıları: Fikir - M.E.; Tasarım - M.E.; Denetleme - M.E.; Veri Toplanması ve/veya işlemesi - A.R., N.R.; Analiz ve/veya Yorum - M.E.; Literatür taraması - A. R.; Yazıyı Yazan - M.E.; Eleştirel İnceleme - A.M.

Teşekkür: Meslektaşlarımızdan Hashemnejad'a ve Hejazi'ye bu çalışmaya olan katkılarından dolayı teşekkür ederiz.

Çıkar Çatışması: Yazarlar çıkar çatışması bildirmemişlerdir.

Finansal Destek: Bu çalışma Razi Vaccine ve Serum Araştırma Enstitüsü tarafından desteklenmiştir.

\section{REFERENCES}

1. Maroto M, Arredondo JJ, San Román M, Marco R, Cervera M. Analysis of the paramyosin/ miniparamyosin gene. Miniparamyosin is an independently transcribed, distinct paramyosin isoform, widely distributed in invertebrates. J Biol Chem 1995; 3: 270: 4375-82. [CrossRef]

2. Cohen C, Szent-Gyo" rgyi AG, Kendrick-Jones J. Paramyosin and the filaments of molluscan "catch" muscles. I. Paramyosin: structure and assembly. J Mol Biol 1971; 56: 223-37. [CrossRef]

3. Kagawa H, Gengyo K, Mclachlan AD, Brenner S, Karn J. Paramyosin gene (unc-15) of Caenorhabditis elegans. Molecular cloning, nucleotide sequence and models for thick filament structure. J Mol Biol 1989; 207: 311-33. [CrossRef]

4. Vino's J, Domingo A, Marco R, Cervera M. Identification and characterization of Drosophila melanogaster paramyosin. J Mol Biol 1991; 220: 687-700. [CrossRef] 
5. Gross Z, Ram D, Markovics A. Schistosoma mansoni: stagespecific expression of muscle-specific genes. Exp Parasitol 1990; 70: 62-71. [CrossRef]

6. Kalinna BH, McManus DP. A vaccine against the Asian schistosome, Schistosoma japonicum: an update on paramyosine as a target of protective immunity. Int J Parasitol 1997; 27: 1213-19. [CrossRef]

7. Limberger RJ, McReynolds LA. Filarial paramyosin-cDNA sequences from Dirofilaria imitis and Onchocerca volvulus. Mol Biochem Parasitol 1990; 38: 271-80. [CrossRef]

8. Laclette JP, Shoemaker CB, Richter D, Arcos L, Pante N, Cohen C, Bing D, et al. Paramyosin inhibits complement C1. J Immunol 1992; 148: 124-8.

9. Muhlschlegel F, Sygulla L, Frosch P, Massetti P, Frosch M. Paramyosine of Echinococcus granulosus: cDNA sequence andcharacterization of a tegumental antigen. Parasitol Res 1993; 79: 660-6. [CrossRef]

10. Flisser A, Woodhouse $E$, Larralde C. Human cysticercosis antigens, antibodies and non-responders. Clin Exp Immunol 1980; 39: 27-37.

11. Flisser A, Espinoza B, Tovar A, Plancarte A, Correa D. Host-parasite relationship in cysticercosis: immunologic study in different compartments of the host. Vet Parasitol 1986; 20: 95-102. [CrossRef]

12. Gobert GN, Stenzel DJ, Jones MK, Allen DE, McManus DP. Schistosoma japonicum: immunolocalization of paramyosin during development. Parasitol 1997; 114: 45-52. [CrossRef]

13. Pearce EJ, James SL, Dalton J, Barrall A, Ramos C, Strand M, et al. Immunochemical characterization and purification of Sm-97, a Schistosoma mansoni antigen monospecifically recognized by antibodies from mice protectively immunized with a nonliving vaccine. J Immunol 1986; 137: 3593-600.
14. Ramı́rez $B L$, Kurtis JD, Wiest $P M$, Arias $P$, Aligui F, Acosta $L$, et al. Paramyosin: a candidate vaccine antigen against Schistosoma japonicum. Parasite Immunol 1996; 18: 49-52. [CrossRef]

15. Li B, Chandrashekar R, Weil G. Vaccination with recombinant filarial paramyosin induces partial immunity to Brugia malagy infection in jirds. J Immunol 1993; 150: 1881-5.

16. Landa A, Laclette JP, Nicholson-Weller A, Shoemaker CB. cDNA cloning and recombinant expression of collagen-binding and complement inhibitor activity of Taenia solium paramyosin (Ag B). Mol Biochem Parasitol 1993; 60: 343-8. [CrossRef]

17. Laclette JP, Alagón A, Willms K, Torre-Blanco A. Purification of antigen B from Taenia solium cysticerci by affinity to mammalian collagen. J Parasitol 1990; 76: 273-5. [CrossRef]

18. Solís CF, Ostoa-Saloma P, Lugo-Martínez VH, Johnston SA, Laclette JP. Genetic vaccination against murine cysticercosis by using a plasmid vector carrying Taenia solium paramyosin. Infect Immun 2005; 73: 1895-7. [CrossRef]

19. Vino's J, Domingo A, Marco R, Cervera M. Identification and characterization of Drosophila melanogaster paramyosin. J Mol Biol 1991; 220: 687-700. [CrossRef]

20. Sambrook J, Fritsch EF, and Maniatis T. Molecular cloning: Alaboratory Manual. New York: Cold Spring Harbor Press; 1989.

21. Vargas-Parada L, Laclette JP. Gene structure of Taenia solium paramyosin Parasitol Res 2003; 89: 375-8.

22. Dean Fraga, Tea Meulia, and Steven Fenster. Real-Time PCR. Current Protocols Essential Laboratory Techniques. John Wiley \& Sons; 2008. p. 3. 7. 10. 